\title{
蝶形骨洞炎由来脳膿瘍例
}

\author{
高木 伸夫・村上 匡孝・大西 弘剛 \\ 福島 龍之・安田 範夫
}

\section{A Case of Rhinogenic Brain Abscess}

\author{
Nobuo Takagi, Masataka Murakami, Hirotsune Onishi, \\ Tatsuyuki Fukushima and Norio Yasuda \\ (Kyoto First Red Cross Hospital)
}

\begin{abstract}
We report a case of rhinogenic brain abscess originating from sphenoidal sinusitis. The patient was a 12-year-old male, who suffered from headache and high fever. The patient underwent emergency hospitalization because of disturbances in consiousness. CT and MRI scans revealed a brain abscess in the left frontal lobe and left sphenoid-ethmoid-maxillary sinusitis. We diagnosed a rhinogenic brain abscess originating from sphenoidal sinusitis. After subdural drainage and antibiotic therapy, surgical treatment under endoscopy was carried out.
\end{abstract}

The patient recovered completely 8 weeks after admission.

Key words : rhinogenic brain abscess, sphenoidal sinusitis, endoscopic surgery

はじめに

抗生物質の進歩とともに鼻性頭蓋内合併症は極めてま れになった。しかし今日に执いても本症の発症は皆無で はなく，常に念頭に括いて日常診療にのぞまないと重篤 な結果を招く扣それがある。最近我々は蝶形骨洞炎由来 と考兄られる鼻性脳膿瘍を経験したので，若干の文献的 考察を加えて報告する.

\section{症例}

患者：12歳，男児.

主訴 : 発熱, 意識障害.

家族歴：特記すべきことなし.

既往歴 : 特記すべきことなし.

現病歴: 平成 8 年 12 月初め頃より発熱と頭痛が出現し, 近医小児科にて内服治療を受ける。症状は一時的に軽快 した後, 再度発熱, 頭痛が出現, 意識レベルが低下した ため，12月11日当院小児科に緊急入院となった。
入院時所見：意識レベル JCS II-20，項部硬直 $(+)$, ケルニッヒ徵候 $(-)$

入院時血液・䯣液検査: 末梢白血球数 $13200 / \mu \mathrm{l}$ (好中 球 $85.7 \%$, リンパ球6.8\%), CRPは $13.5 \mathrm{mg} / \mathrm{dl}$, 蛋白 分画はアルブミン分画 $58.6 \%, \alpha 1$ 分画 $3.9 \%, \alpha 2$ 分画 $14.4 \%, \beta$ 分画 $10.2 \%, \gamma$ 分画 $12.9 \%$ であった. その他 特記すべき異常所見はなかった．髄液所見は細胞数6198 $/ \mu \mathrm{l}$, 総蛋白量 $47 \mathrm{mg} / \mathrm{dl}$, 糖量 $60 \mathrm{mg} / \mathrm{dl}$ であった. 髄液 の細菌検查では菌は同定できなかった.

経過: 細菌性䯣膜炎の診断下に, 入院後直ちに抗生物 質(ABPC $6 \mathrm{~g} /$ 日，CRP $4 \mathrm{~g} /$ 日)投与と $\gamma$-グロブリン製 剂を 2 日間併用した (図 1 )。入院時の頭部 CT 検查では 左被殼部に軽度の低吸収域を認めたが(図 2), その他腫 瘍陰影などの異常所見を認めなかった。治療開始後, 意 識レベルは変動し, それに加えて12月18日頃より, 右手 指の運動障害, 右バビンスキー反射陽性, 右中枢性顔面 神経麻痺, 右舌下神経麻痺が出現したため, 左側の脳幹 


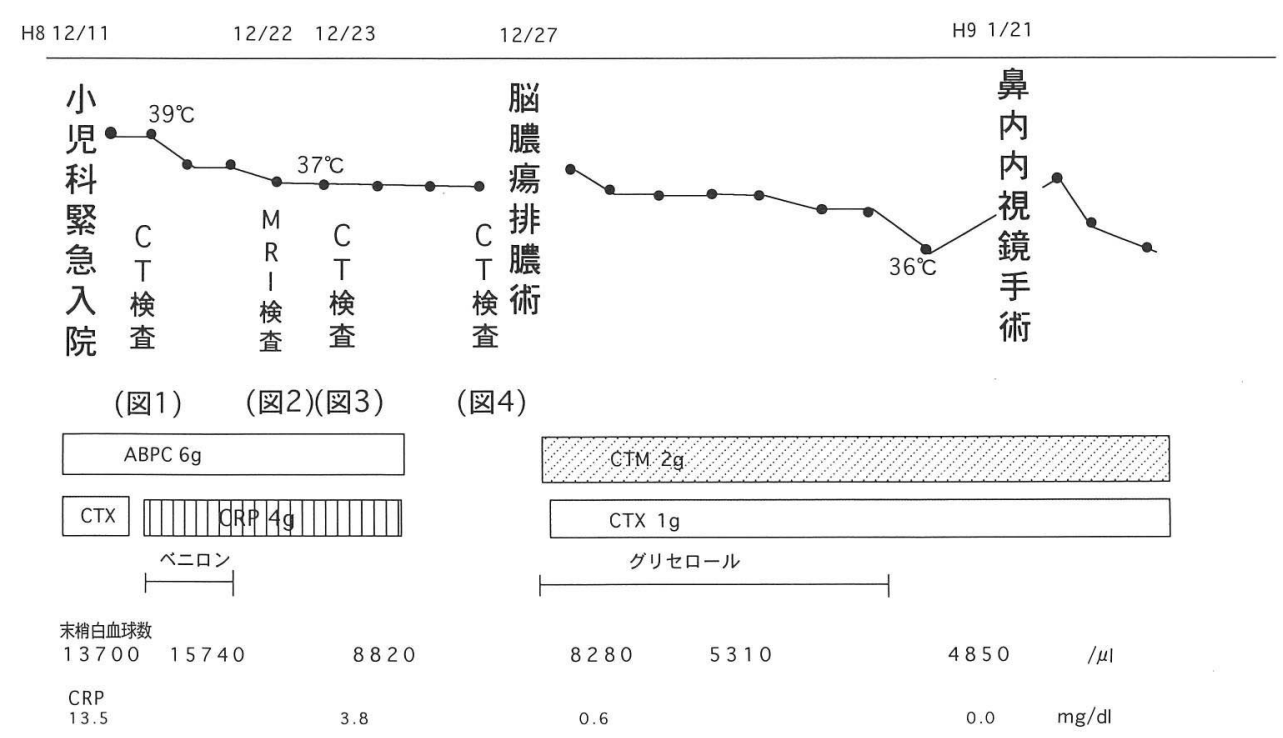

図 1 臨床経過

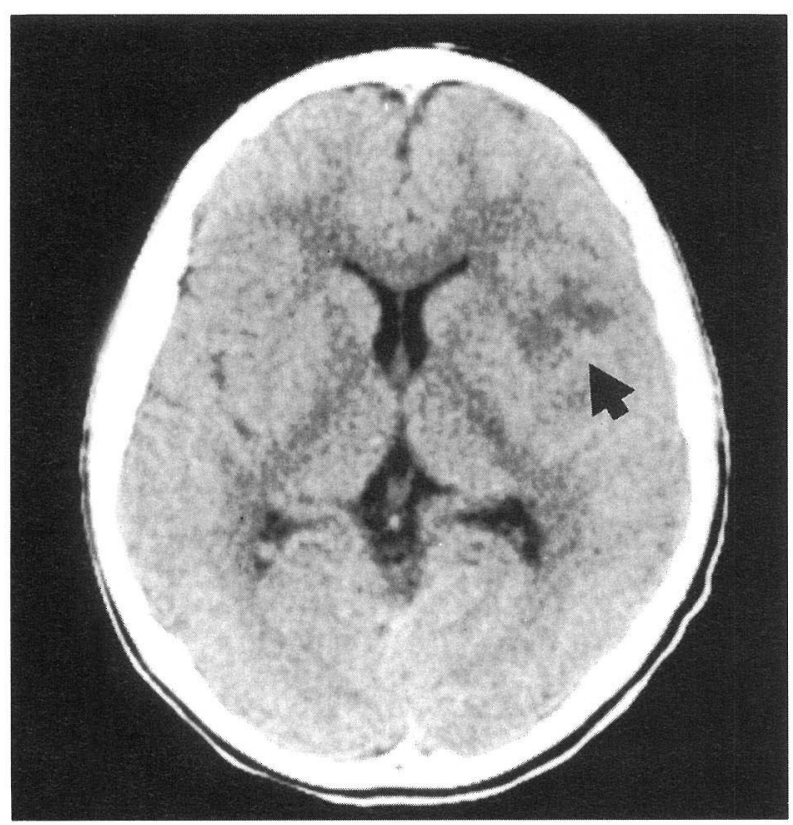

図 2 頭部 CT (初診時)

左被殼部に軽度の低吸収域(矢印)を認めるが，腫瘍陰影 などを認めなかった。

または，左大脳皮質障害を疑い，12月22日，再度 MRI 検査を施行したところ，T1 で高信号，Gd-DTPA 造影 にて周囲がリング状に増強効果がある内部が低信号の像 を認め, 脳膿瘍と判明した(図 3 )。をた, 蝶形骨洞にも
高信号の像を認めたため，副鼻腔 CT 検査を施行したと ころ, 両側蝶形骨洞, 左上顎洞, 左篩骨洞に副鼻腔炎様 陰影を認め(図 4), 蝶形骨洞炎由来の鼻性脳膿瘍と診断 した. 引き続き施行した化学療法にもかかわらず, 症状 は増悪し, 膿瘍周囲の浮腫も明らかに増悪してきたため (図 5 )，12月27日脳神経外科にて，緊急ドレナージ手術 が施行された. 約 $7 \mathrm{cc}$ の膿汁を吸引し，持続ドレーン を执いて手術を終了した。採取した膿汁の培養に执いて は菌は検出できなかった。 この時点では耳鼻科では手術 を施行しなかった. 術後の化学療法の継続によって, 炎 症症状, 臨床症状とも徐々に改善傾向を認めたので,さ らに経過を観察した後, 翌年 1 月 21 日に全身麻酔下に内 視鏡下鼻内副鼻腔手術を施行した。

術中所見：手術は中鼻道よりアプローチし，前管骨洞， 上顎洞, 後篩骨洞を開放し, 後篩骨洞より蝶形骨洞を開 放した．洞を開放したところ少量の膿汁が認められた. 洞内には軽度の粘膜肥厚を認めたものの, 骨欠損は認め られなかった。術中に採取した鼻汁を培養したところ表 皮ブドウ球菌が検出された. 術後経過良好にて，2月 1 日後遺症を残さず退院となった. 術後 3 力月後の頭部 MRI に执いても膿瘍陰影を認めず(図6), 副鼻腔 CT でも副鼻腔炎陰影の改善を認めている(図7). 現在外来 にて経過観察中である. 

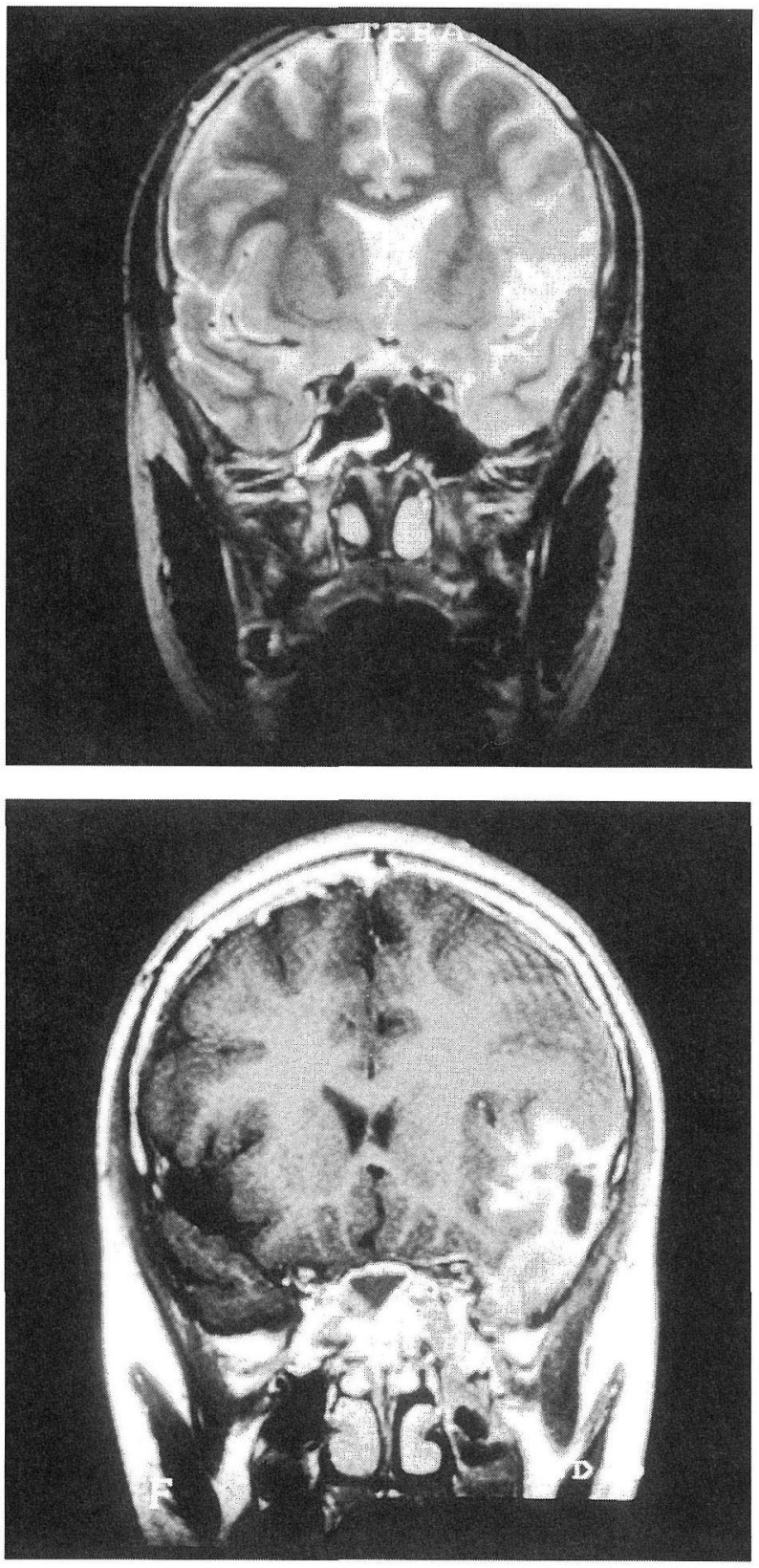

図 3 頭部 MRI (12月22日)

$\mathrm{T} 1$ 強調画像にて高信号 (図上), Gd-DTPA にて周辺が リング状に造影効果を受け内部低信号の陰影を左側頭葉 に認めた。をた，蝶形骨洞内にも高信号を呈する病変を 認めた(図下).

\section{考察}

鼻性頭蓋内合併症は原因別に自然発症, 術後性, 外傷 性に分けられているが，近年では術後性の原因が減少し ているが，交通事故の増加によって外傷性が増加傾向に
ある112)。性別では男性に多いと言われている，発症年 齢は10歳代，20歳代の若年者に多いとされ，その理由と 乙て，若年者は扁平骨が赤色骨髄であるために前頭骨骨 髄炎が発症しやすいと言われている3)4.

感染経路については，一般的に馬場5) は次の 3 つを挙 げている。

（1）脈管系を介するもので，静脈系とリンパ系に大別 される.さらに静脈系は副鼻腔壁の穿通静脈を介する経 路と, 粘膜内小静脈より海綿静脈洞へ侵入するものがあ る. 特に硬膜と前頭洞粘膜を自由に交通している板間静 脈の穿通静脈は并構造を持たないため, 細菌が逆行し頭 蓋内に侵入する可能性がある。一方で鼻粘膜と頭蓋内の リンパ管の直接交通や，前頭洞後壁の穿通血管の周辺を 走るリンパ管の関与も考えられる.

（2）骨欠損・病変部に由来するもので，先天性または 老人性骨萎縮による骨欠損，手術操作，外傷による骨壁 の損傷，穿破部からの頭蓋内感染がある。この場合，副 鼻腔病変部に一致した硬膜に直接感染が波及して硬膜外 膿瘍となり，さらに䯣膜炎や脳膿瘍に発展している。

（3）隣接器官を介するもので，炎症がいったん眼窩や 翼口蓋窩に波及し，頭蓋内に至るものである。ことに眼 窩経由のものに注意が必要とされている.

本症例では外傷, 副鼻腔炎の手術の既往もなく，また， 手術所見，画像診断から，骨欠損に由来するものではな く，脈管系を介して感染を起こした可能性が最も大きい と考えられる。

原病巣の部位別頻度からみると, 以前は術後性のタイ プに多い篩骨洞原発が多く，現在では前頭洞原発のもの が最も多いとされている2)、いずれにせよ鼻性頭蓋内合 併症の注之んどの症例が前頭洞，飾骨洞由来であり， CT・手術所見から自験例である蝶形骨洞由来の症例は まれとされている2667)。鈒持ら日)によと蝶形骨洞炎が 鼻性頭蓋内合併症の起こる解剖学的機序として, 蝶形骨 洞の周囲には重要な血管，神経が隣接して拈り，洞内に 隆起構造を形成している。蝶形骨洞の外側壁には海綿静 脈洞があり，その中を内頸動脈，三叉神経 (一枝，二枝）, 動眼神経, 滑車神経, 外転神経が走行して扐り, 特に, 内頸動脈はその中でも最も正中寄りにあり，これら洞骨 壁に菲薄した部分に炎症や軽度の外傷により，容易に骨 破壊など骨欠損をさたして頭蓋内へ感染しやすいためと 考えられている。

また，蝶形骨洞の血行としては，洞内粘膜の静脈叢は 

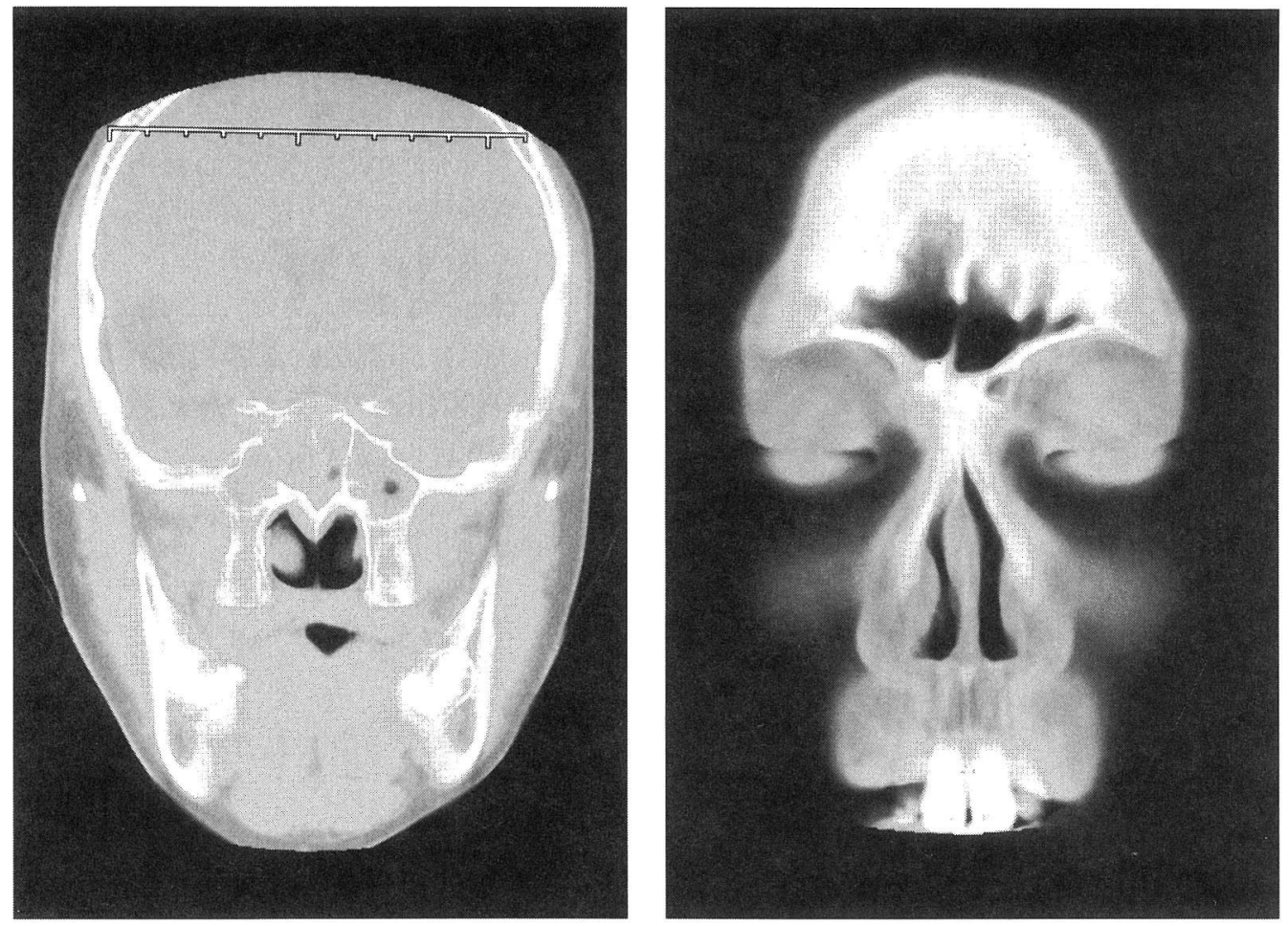

図 4 副鼻腔 CT (12月23日)

両側蝶形骨洞に陰影を認めた(図左)。しかし，前頭洞には陰影を認めなかった(図右)。

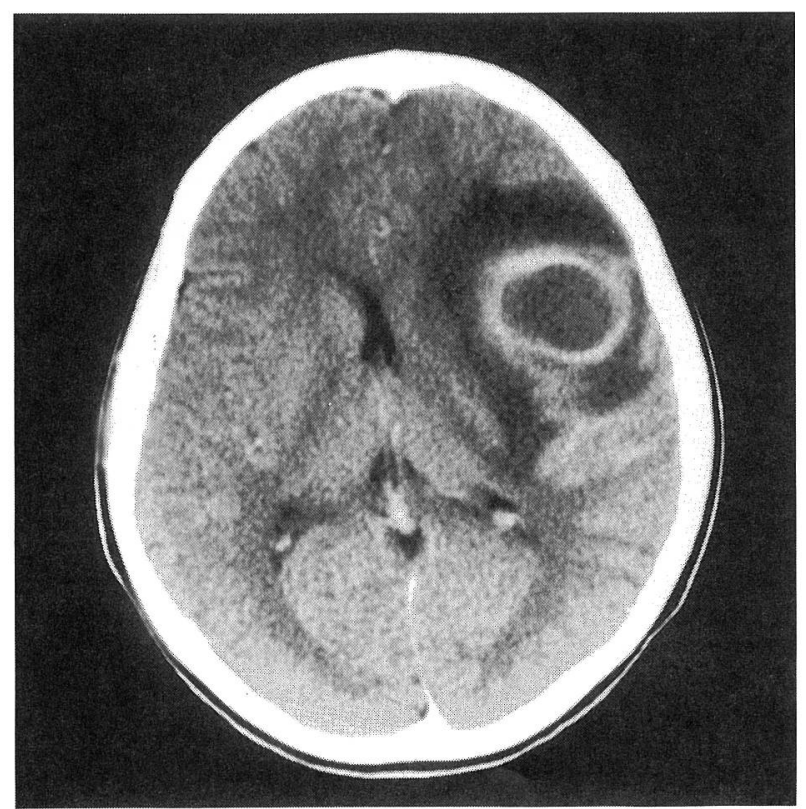

図 5 頭部 CT (12月27日)

左側頭葉にリング状に増強効果のある腫瘤様陰影を認 め, また，膿瘍周囲の浮腫の増強を認める。

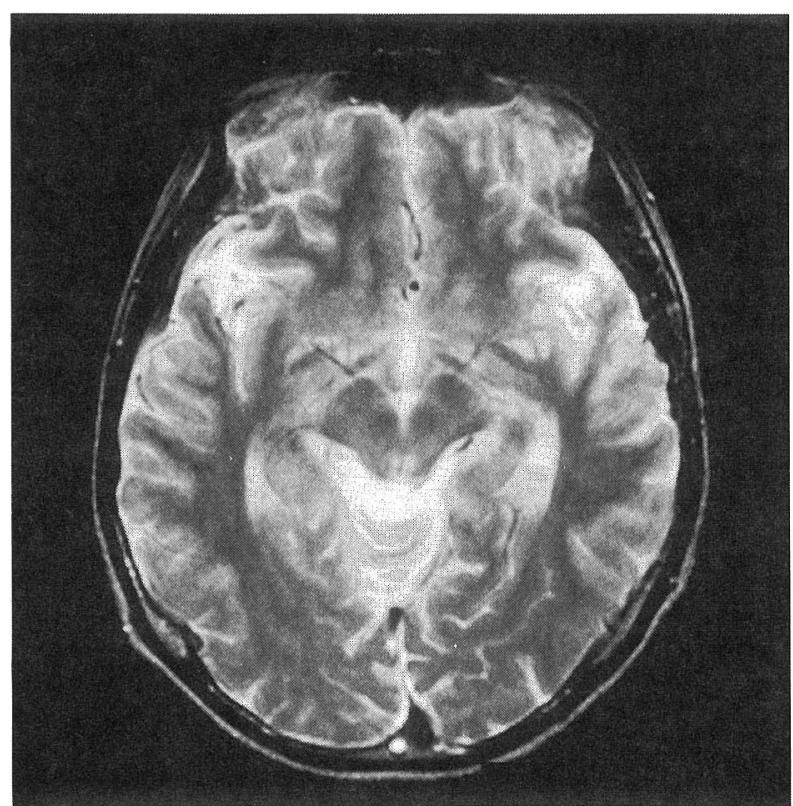

図 6 頭部 MRI（術後 3 カ月） 膿瘍陰影は消失している。 

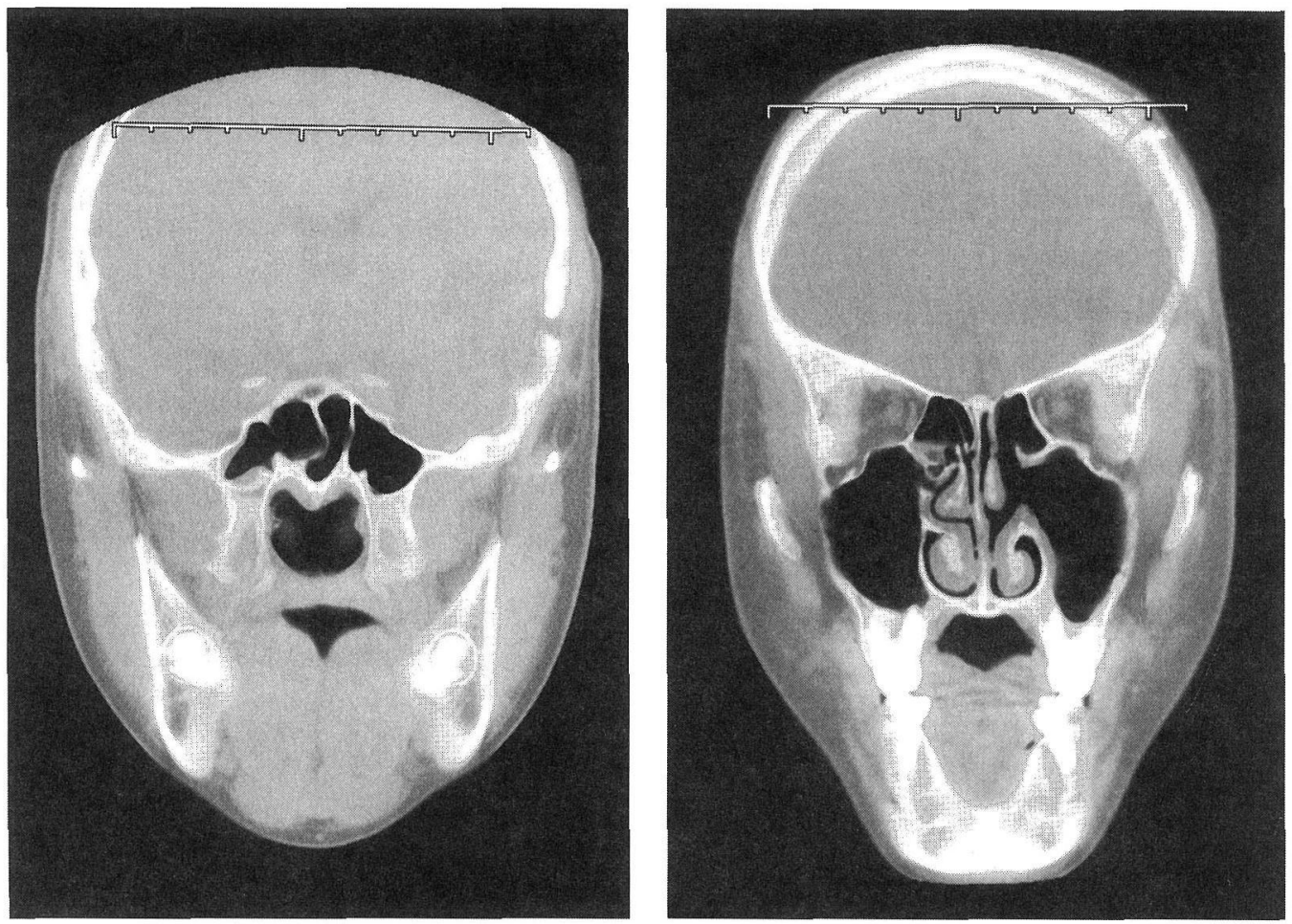

図 7 副鼻腔 $\mathrm{CT}$ (術後 3 力月) 両側蝶形骨洞，左篩骨洞，左上顎洞の陰影は消失している。

自然口を通り，鼻腔，咽頭に達するが，骨壁を貫いて後 部節骨洞静脈, 上眼静脈を経由乙て海綿静脈叢へ交通す る経路があり，そのため，蝶形骨洞炎の起因菌が脈管系 を介して頭蓋内に波及しやすいことを挙げている。

合併症別頻度からみると，以前は髄膜炎が圧倒的飞多 かったが，最近は減少して多彩な像を呈している9110). これは抗生物質の進歩により，以前なら髄膜炎に至った 症例が治瘉し，抗生物質などの薬物療法で治癒しない重 症例が膿瘍形成まで進展してしまうためと思われる。今 回経験した症例も䯣膜炎で発症し，脳膿瘍にまで進展し たものと考穴られる。

頭蓋内合併症は細菌によるものが多く、インフルェン ザ菌, 髄膜炎菌, 肺炎球菌の 3 種類が多く， 8 割以上を 占めていると言われている．なた，嫌気性菌培養の技術 が改良されるに従い嫌気性菌が検出される頻度が高くな った2)9111)。今回の症例では，髄液，ドレナージ手術の際 飞採取した膿汁，鼻漏など検査を施行したが，同定でき たのは鼻漏から表皮ブドウ球菌だけだった。

治療に関しては早期発見，早期治療が原則であるが，
本疾患は汪とんどがが゙症状で発症し，耳鼻咽喉科以外 を受診し，鼻内を観察されないまま経過したり，抗生物 質投与により鼻内の炎症所見が消失したり軽微になるこ とが多く，副鼻腔炎に気つかない事も少なくない。治療 は強力な化学療法と副鼻腔原病巣の手術が基本となる. さらに頭蓋内の膿瘍形成に至れば脳神経外科的手術が必 要となる. 問題となるのは手術の時期である. 早期に施 行するか否かは定説はないが，診断がつき次第なるべく 早期に手術を施行し，原因除去に心掛けるべきと考光ら れている1112) 14). 今回の症例では，先に施行された脳神 経外科によるドレナージ手術と耳鼻科による副鼻腔炎手 術との間任約 1 力月市り, 患者の負担孔考光ると, 一度 にすべきであったと反省している。立，今回蝶形骨洞 を内視鏡手術による経篩骨洞アプローチにより開放した が，内視鏡を利用することにより，視神経管，天蓋，眼 窩紙様板など危険部位を認知した上で，篩骨洞，蝶形骨 洞，上頡洞，鼻前頭管の開放，処置が安全かつ的確にで きる、また，小児のような狭い鼻腔でも十分対応できる ことを再認識した ${ }^{15116)}$. 


$$
\text { まとめ }
$$

1 ) 蝶形骨洞由来と考吕られる鼻性頭蓋内合併症(脳 膿瘍)の 1 例を経験した.

2 ）治療は化学療法, 脳膿瘍排膿手術特よび鼻内内視 鏡手術を施行した.

3 ）鼻内内視鏡手術を施行することで良好な視野が得 られ，安全かつ的確に手術操作が可能であった.

本論の要旨は第59回耳鼻咽喉科臨床学会(京都市)にてロ演し た.

稿を終えるにあたり御校閲を賜りました京都府立医科大学耳 鼻咽喉科学教室村上 泰教授に深謝いたします。

\section{参考文献}

1) 三浦 巧, 持田 晃, 本杉英昭 : 最近経験した鼻性頭蓋内 合併症の 4 例. 耳鼻臨床 $86: 971 \sim 978,1993$.

2 ）野久山晴子, 佐藤達明, 白木直也：蝶形骨洞由来の鼻性脳 膿瘍の 1 治験例. 耳鼻臨床 補73: 106 113, 1994.

3 ）佐藤成樹, 上杉恵介, 菊地原基敬 : 鼻性脳膿瘍の 1 症例. 耳鼻臨床 補 $9: 202 \sim 209,1987$.

4) 井沢勇作 : 前頭洞骨髄炎. 耳展 $2: 272 \sim 274,1959$.

5 ) 馬場駿吉 : 視神経炎, 翼口蓋窩, 頭蓋内合併症(鼻)。耳展 $52: 747 \sim 750,1989$.

6 ）由井誠一郎, 福喜多啓三, 福家博史 : 鼻性頭蓋内合併症の 1 例. 耳鼻臨床 72 増 $2: 1312 \sim 1320,1981$.
7 ）木村恭之，上出文博，梅田良三 : 急性前頭洞炎に合併した 硬膜外膿瘍の発症原因々考察. 耳展 32 : 167 174, 1989.

8 ）鈒持 睦, 岡田智幸, 岩沢 寛：髄膜炎を併発した原発性 蝶形骨洞炎.耳鼻臨床 補 $48 ： 175 \sim 179,1991$ 。

9 ）宮下 弘, 大川靖弘, 丸地孝昌 : 保存治療で治癒した鼻性 硬膜外膿瘍の 1 例. 耳鼻臨床 補60：103〜109, 1992.

10）伊従秀章, 樋口 薫, 林 良寛: 硬膜下 - 副鼻腔膿瘍の 1 例. 小览科臨床 $44: 2487 \sim 2492,1991$.

11）外園泰弘, 山添一郎，青木修一郎：副鼻腔炎より発症した 頭蓋内膿瘍の 2 例．小児科臨床 $44 ： 141 \sim 144,1991$.

12）田中和成，松村憲一：鼻性頭蓋内合併症．耳鼻臨床 89： $1451 \sim 1457,1996$.

13）青柳 聡, 平山方俊, 金子 功 : 鼻性硬膜下膿瘍の 1 症例. 耳鼻臨床 補42：91～96, 1991

14）金澤丈治，楠見 彰，知念信雄 : 慢性副鼻腔炎に合併した 硬膜下膿瘍例．耳鼻臨床 $87 ： 651 \sim 658,1994$.

15）北村達也, 児玉 実, 萩原一郎 : 急性前頭洞炎に起因する 硬膜下膿瘍の 1 例. 耳展 $34: 341 \sim 346,1991$.

16）福島龍之, 村上匡孝, 安田範夫：当院に打ける小児副鼻腔 炎手術の現状と問題点. 小児耳 $17: 57 \sim 61,1996$.

$\left(\begin{array}{l}\text { 原稿受付 : 平成 } 9 \text { 年 } 9 \text { 月 } 12 \text { 日 } \\ \text { 原稿採択 : 平成 } 9 \text { 年 } 10 \text { 月 } 22 \text { 日 } \\ \text { 別刷請求先 : 高木伸夫 } \\ \text { 干 } 673-0848 \text { 明石市鷹匠町 } 1-33 \\ \text { 明石市立市民病院耳鼻咽喉科 }\end{array}\right)$

